\title{
Flora do Ceará: Pontederiaceae
}

\author{
Flora of Ceará: Pontederiaceae
}

Danilo José Lima de Sousa ${ }^{1,4}$, Maria Jaciane de Almeida Campelo ${ }^{2}$ \& Lígia Queiroz Matias ${ }^{3}$

\begin{abstract}
Resumo
Pontederiaceae está representada no estado do Ceará por 10 espécies, distribuídas em quatro gêneros: Eichhornia, Heteranthera, Hydrothrix e Pontederia. O gênero Eichhornia foi o mais representativo com cinco espécies: E. crassipes. E. diversifolia, E. heterosperma, E. paniculata e, pela primeira vez, E. paradoxa está citada para o estado. O segundo gênero em número de espécies foi Heteranthera, com três espécies: $H$. oblongifolia, H. rotundifolia e H. seubertiana. Os gêneros Hydrothrix e Pontederia encontram-se representados, cada um, por apenas uma espécie: Hydrothrix gardneri e Pontederia parviflora. As espécies predominam em ambientes aquáticos temporários, porém as espécies submersas (Heteranthera seubertiana e Hydrothrix gardneri) são mais comuns em riachos e rios perenes. Incluem-se neste estudo, chaves de identificação dos táxons, breves descrições das espécies, mapa da distribuição geográfica e ilustrações.
\end{abstract}

Palavras-chave: áreas inundadas, hidrófitos, plantas aquáticas, regiões áridas.

\begin{abstract}
Pontederiaceae is represented in Ceará state by 10 species, distributed in four genera: Eichhornia, Heteranthera, Hydrothrix and Pontederia. The genus Eichhornia was the most represented with five species: E. crassipes, E. diversifolia, E. heterosperma, E. paniculata and, for the first time cited to Ceará, E. paradoxa. The second genus in species number was Heteranthera, with three species: H. oblongifolia, H. rotunfdifolia and H. seubertiana. Hydrothrix and Pontederia are represented just by one species each: Hydrothrix gardneri and Pontederia parviflora. The species predominate in temporary aquatic environments; however, the submerged species (Heteranthera seubertiana and Hydrothix gardneri) are more common in perennial streams. Identification keys, species descriptions, maps of species distributions and illustrations are included.
\end{abstract}

Key words: wetlands, hydrophytes, aquatic plants, arid regions.

\section{Introdução}

As Pontederiaceae são ervas aquáticas perenes ou mais raramente anuais, que se encontram enraizadas no substrato com partes vegetativas submersas, flutuantes ou emergentes, ou ainda, podem ser ervas flutuantes não enraizadas que se deslocam livremente pela lâmina d'água (Machado 1947; Cook 1996, 1998). Seus representantes são caracterizados principalmente pelas flores zigomorfas, homoclamídeas, com perigônio fusionado formando um tubo curto ou muito desenvolvido (Cook 1996, 1998). As inflorescências são frequentemente descritas como racemos, espigas ou tirsos, mas podem ser consideradas de maneira ampla como inflorescências cimosas. Porém, em algumas espécies, as flores são encontradas aos pares ou em unidades isoladas, formando muitas vezes pseudantos bifloros como os encontrados em Hydrothrix gardneri Hook.f. (Sousa \& Giulietti 2014).

Os primeiros estudos filogenéticos baseados em dados morfológicos sustentaram o monofiletismo de Pontedericeae (Eckenwalder \& Barrett 1986). Análises filogenéticas subsequentes

\footnotetext{
${ }^{1}$ Universidade Estadual de Feira de Santana, Prog. Pós-graduação em Botânica, Depto. Ciências Biológicas, Av. Transnordestina s/n, Novo Horizonte, 44036-900, Feira de Santana, BA, Brasil.

${ }^{2}$ Universidade Federal do Vale do São Francisco, Centro de Referência para Recuperação de Áreas Degradadas da Caatinga, BR-407, km 12, lote 543, Projeto de Irrigação Nilo Coelho - S/N C1, 56300-000, Petrolina, PE, Brasil.

${ }^{3}$ Universidade Federal do Ceará, Centro de Ciências, Depto. Biologia, Lab. Taxonomia de Angiospermas, bl. 906, Campus do Pici, 60451-760, Fortaleza, CE, Brasil.

${ }^{4}$ Autor para correspondência: danilojls@yahoo.com.br
} 
baseadas em dados moleculares, tanto plastidiais quanto nucleares, confirmaram o monofiletismo da família (Graham \& Barrett 1995; Graham et al. 1998; Graham et al. 2002). Entretanto, os grupos infrafamiliares como as tribos Eichhornieae, Pontederieae e Heteranthereae (sensu Schwartz 1926), assim como os gêneros Eichhornia, Pontederia e Heteranthera apresentaram-se como grupos não monofiléticos (Ness et al. 2011).

Os representantes de Pontederiaceae apresentam distribuição Pantropical, sendo descritos cerca de seis gêneros e 33 espécies (The Plant List 2013). Os gêneros com distribuição mais ampla são: Eichhornia Kunth ( 7 spp.), Heteranthera Ruiz et Pav. ( 11 spp.) e Pontederia L. ( $\sim 6$ spp.), enquanto que Monochoria Presl. ( $\sim 7$ spp.) possui ocorrência indicada para África, Ásia e Austrália. Por outro lado, os gêneros Scholleropsis H. Pers (uma sp.) é endêmico de Madagascar e Hydrotrhrix Hook. (uma sp.) possui sua distribuição restrita à região semiárida do Brasil (Hooker 1887; Cook 1996; Sousa \& Giulietti 2014; Sousa 2017). A região Neotropical apresenta a maior riqueza de táxons, sendo estimadas cerca de 25 espécies, o que representa mais de $80 \%$ das espécies da família (Seubert 1847; Schulz 1942; Castellanos 1958; Novelo \& Ramos 1998; Crow 2003). Entre os países situados na região Neotropical, o Brasil é detentor da maior diversidade com 23 espécies registradas, com indicação de 10 espécies para o estado do Ceará (BFG 2015; Sousa 2017).

As Pontederiaceae apresentam um importante papel nas comunidades dos ambientes dulcícolas, nos quais são frequentes, como registrado nos principais levantamentos da flora aquática para a Região Nordeste do Brasil (Matias et al. 2003; Giulietti et al. 2006; França \& Melo 2006; Neves et al. 2006; Henry-Silva et al. 2010). Estudos florísticos específicos com a família permitirão a aquisição e ampliação do nosso conhecimento sobre a biota de ambientes aquáticos, temporários e perenes. Desta forma, este trabalho objetiva o estudo das espécies de Pontederiaceae ocorrentes no Ceará, incluindo a descrição da variabilidade morfológica encontrada nas populações, preparação de chaves de identificação e ilustrações, assim como, apresentação dos dados sobre a distribuição das mesmas. O trabalho é ainda uma contribuição ao projeto Flora do Ceará.

\section{Material e Métodos}

Os espécimes foram amostrados através de coletas em expedições esporádicas, realizadas principalmente no período chuvoso de 2009 a 2015, assim como, pelo levantamento de materiais depositados nos herbários ALCB, EAC, ESA, GH, HRCB, HRB, HST, HUEFS, HURB, HVASF, INPA, IPA, MAC, MBM, MO, MOSS, NY, R, $\mathrm{RB}$, SP, SPF, UEC, UFP, UFPB e UNA (as siglas seguem Thiers, continuamente atualizado). A identificação foi realizada através de consulta a bibliografia específica (Castellanos 1958; Lowden 1973; Horn 1985; Sousa \& Giulietti 2014). Os espécimes coletados foram herborizados seguindo a metodologia de Haynes (1984) e Ceska (1986) e depositados no Herbário EAC. Os nomes dos autores estão de acordo com IPNI (continuamente atualizado). A terminologia segue Radford et al. (1974) e Sculthorpe (1967). No entanto, os lobos florais foram descritos utilizando a terminologia recentemente proposta por Sousa \& Giulietti (2014), onde (1) os lobos do verticilo externo foram definidos como um mediano anterior e dois laterais posteriores; e (2) os lobos do verticilo interno foram definidos como um mediano posterior e dois laterais. Os dois lobos laterais do verticilo interno quando associados ao lobo anterior são denominados de "anteriores" (disposição $3+3$ ) e quando associados ao lobo posterior são denominados de "posteriores" (disposição 5+1). Os dados de distribuições geográfica das espécies foram extraídos de Lowden (1973), Horn (1985), Cook (1996, 1998), BFG (2015) e Sousa (2017), além da obtenção de dados dos espécimes coletados e registrados em herbários. O sistema de quadriculas georreferenciadas com grade de $0,5^{\circ}$ foi utilizado para a distribuição geográfica das espécies (Fig. 1), o qual vem sendo tradicionalmente utilizado para a Flora do Ceará (Matias \& Sousa 2011). A ocorrência das populações foi determinada através das coordenadas obtidas por GPS (em campo) ou com base nos dados de registro de Herbários.

\section{Resultados e Discussão}

Tratamento taxonômico

Pontederiaceae Kunth in Humb., Bonpl. \& Kunth, Nova Gen. Sp. 1, ed. 40: 265 (1816), nom. cons.

Ervas dulcícolas, perenes ou anuais, emergentes, flutuantes fixas, flutuantes livres ou submersas, rizomatosas ou estoloníferas. Raízes numerosas, não septadas. Folhas alternas, dísticas, espiraladas ou verticiladas, ao longo do caule ou basais, heteromórficas; pecíolos cilíndricos, ocasionalmente inflados; limbos lineares, filiformes a ovais, ápice agudo a arredondado, base atenuada 
a sagitada, margem inteira, venação acródroma a campilódroma. Eixo reprodutivo curto ou longo, frequentemente finalizando em uma bráctea e uma inflorescência. Bráctea desenvolvida, semelhante às folhas ou levemente reduzidas. Inflorescência pedunculada, determinada, cimeiras simples, cincinos ou tirsos (paniculados ou espiciformes) com subunidades de cincinos, 3- ou multi-flora, ou

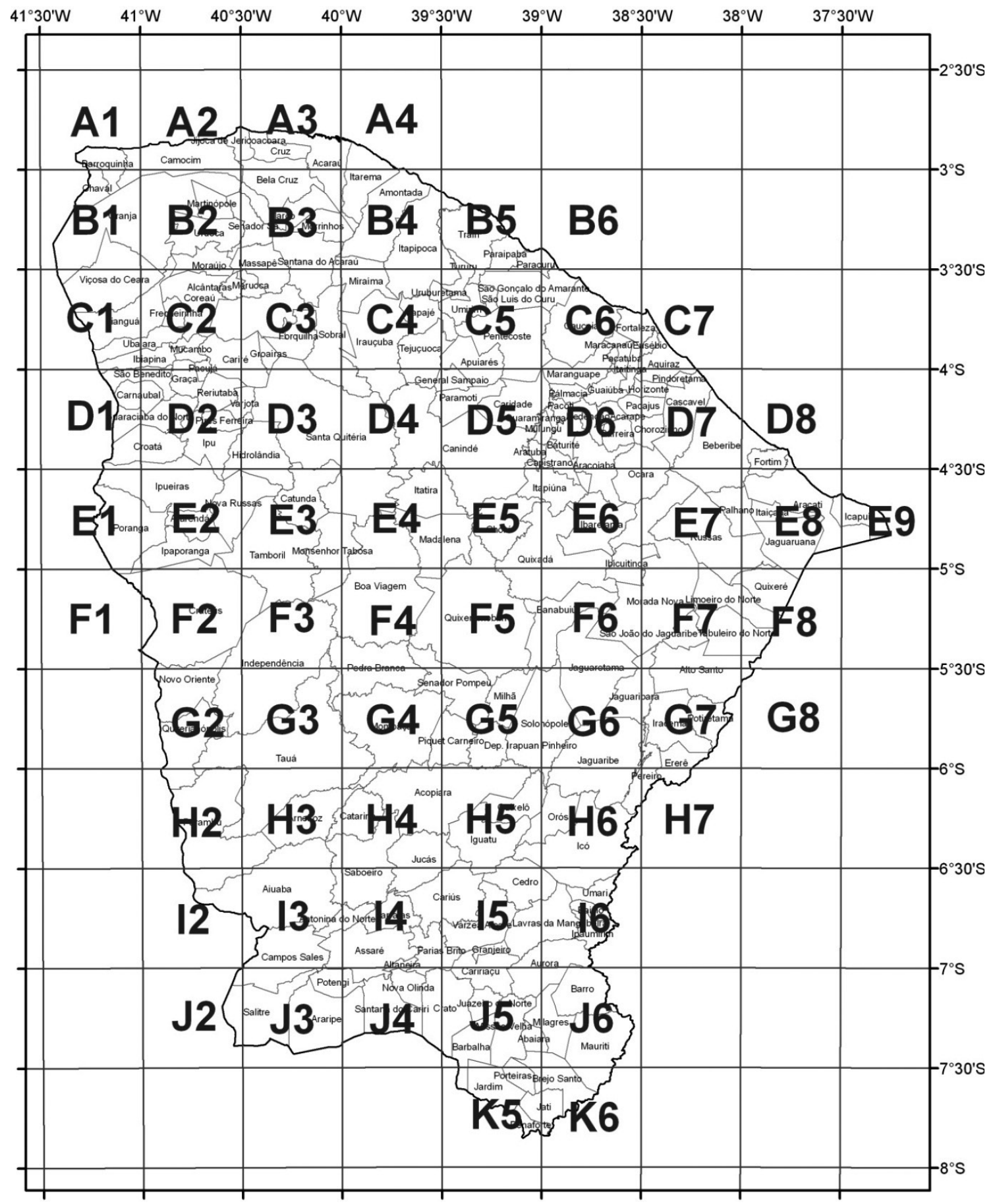

Figura 1 - Mapa do estado do Ceará (CE), Brasil, evidenciando o sistema de quadrículas georreferenciadas. Figure 1 - Map of Ceará state (CE), Brazil, showing the system of georeferenced squares grid. 
reduzidas a inflorescências 1-2-floras; pedúnculo longo, raramente ausente; bractéola aberta ou fechada, frequentemente cimbiforme, oboval a lanceolada ou triangular, raramente ausente, ápice mucronado. Flores trímeras, bissexuadas, sésseis, raramente curto pediceladas; perigônio formado por 3 tépalas externas e 3 tépalas internas, unidas na base em um tubo curto ou longo, externamente sem tricomas ou com tricomas geralmente glandulares; lobos externos geralmente elípticos, 1 mediano anterior e 2 laterais posteriores; lobos internos geralmente ovais, 1 mediano posterior e 2 laterais anteriores $(3+3)$ ou posteriores $(5+1)$; zigomorfo, lilás, azul, amarelo ou branco, lobo mediano posterior geralmente com guia de néctar basal ou mediano, face abaxial dos lobos acompanhando o indumento do tubo; androceu com 1, 3 ou 6 estames, livres entre si, adnatos ao tubo do perigônio, anteras 2 -tecas, basifixas a dorsais, rimosas; carpelos 3 , sincárpicos, ovário súpero, trilocular, multiovulado ou uniovulado, placentação apical, axilar ou parietal intrusiva, óvulos anátropos, estilete curto ou longo, estigma capitado ou lobado. Fruto cápsula loculicida ou utrículo, frequentemente com o tubo do perigônio persistente, formando um antocarpo desenvolvido (alado ou equinado) ou não (não alado, não equinado, se rasgando com o desenvolvimento do fruto). Sementes nmerosas ou 1 semente por fruto, testa glabra, lisa ou costada longitudinalmente, castanho claras a escuras.

\section{Chave de identificação dos gêneros de Pontederiaceae do Ceará}

1. Flores com 6 estames

2. Ovário com 3 lóculos férteis, multiovulados; fruto cápsula loculicida; sementes costadas

2'. Ovário com apenas 1 lóculo fértil, uniovulado; fruto utrículo; sementes lisas......... 4. Pontederia

1. Eichhornia

1'. Flores com 1 ou 3 estames

3. Plantas com filotaxia alterna dística ou espiralada; limbo filiforme ou oblongo a arredondado; 3 estames, raramente 1 estame e 2 estaminódios. 2. Heteranthera

3'. Plantas com filotaxia verticilada; limbo linear; 1 estame, estaminódios ausentes.... 3. Hydrothrix

1. Eichhornia Kunth, Enum. Pl. 4: 129-132. 1843. Ervas emergentes, flutuantes fixas ou flutuantes livres. Folhas alternas, dísticas ou espiraladas, basais ou ao longo do caule, emersas ou flutuantes, pecioladas; pecíolos inflados ou não, cilíndricos; limbos lanceolados ou circulares a amplo ovais; ápice agudo a arredondado; base atenuada a cordada. Eixo reprodutivo curto ou longo. Bráctea semelhante às folhas ou levemente reduzidas. Inflorescências cimeiras simples, cincinos ou tirsos (2-)3- ou multiflora; pedúnculo longo, raramente ausente; raque glabra ou pubescente; bractéola aberta ou fechada, frequentemente cimbiforme, oboval ou triangular, raramente ausente. Flores lilases, tubo do perigônio com face externa glabra ou pubescente; lobos externos com margem inteira, elípticos, lobos internos com margem inteira, erosa ou fimbriada, obovais, $(3+3)$, lobo mediano posterior geralmente com guia de néctar; estames 6 , filetes cilíndricos, brancos a lilases, glabros, pubescentes ou pilosos, anteras homomorfas, elípticas a sagitadas, basifixas, azuladas ou amarelas; ovário lilás, verde ou vináceo, glabro, trilocular, lóculos todos férteis, multiovulados, estilete vináceo a branco, glabro, pubescente ou viloso, estigma capitado ou lobado, branco a lilás. Cápsula loculicida castanha, vinácea a esverdeada; antocarpo enegrecido, torcido no ápice ou não, liso, não alado. Sementes elipsóides, oblongas ou botuliformes, costadas.

As espécies do gênero podem ser facilmente distintas pelas inflorescências laxas e por apresentar as maiores flores dentre as Pontederiaceae. Além disto, o androceu formado por seis estames e por anteras homomorfas e o ovário com três lóculos multiovulados, gerando um fruto do tipo cápsula loculicida, podem ser considerados caracteres de importância taxonômica. Entretanto, as análises filogenéticas resgatam o gênero como um grupo polifilético, formado por quatro linhagens distintas (Graham et al. 2002; Ness et al. 2011; Sousa et al. 2016a). É um gênero com ampla distribuição, apresentando cerca de seis espécies, todas ocorrendo no Brasil (BFG 2015; Sousa 2017). Para o Ceará foram registradas cinco espécies. 


\section{Chave de identificação das espécies de Eichhornia do Ceará}

1. Plantas flutuantes livres ou emergentes, eretas, folhas basais; estilete piloso, pubescente ou viloso.

2. Pecíolo frequentemente inflado; bráctea reduzida; estilete pubérulo na porção apical 1.1. Eichhornia crassipes

2'. Pecíolo nunca inflado; bráctea semelhante às folhas; estilete piloso ou viloso na porção apical

3. Limbo largo oval; inflorescências tirsos paniculados, pedunculadas, bractéola triangular; estilete piloso................................................................. 1.4. Eichhornia paniculata

3'. Limbo estreito elíptico a estreito lanceolado; inflorescências em cincinos, não pedunculadas, bractéola ausente; estilete viloso 1.5. Eichhornia paradoxa

1'. Plantas flutuantes fixas, decumbentes, folhas ao longo do caule; estilete glabro

4. Folhas flutuantes; inflorescências (2)3--floras; lobos internos com margem inteira.

1.2. Eichhornia diversifolia

4'. Folhas emersas; inflorescências 7-11-floras; lobos internos do perigônio com margem erosa...... 1.3. Eichhornia heterosperma

1.1. Eichhornia crassipes (Mart.) Solms., Monogr. Phan. 4: 527. 1883. Figs. 2a,b; 4a

Erva flutuante livre, raramente emergente, ereta, $15-35 \mathrm{~cm}$ alt. Folha emersa, alterna, espiralada, basal; pecíolo inflado quando flutuante livre, 10-24 × 0,3-2,5 cm, verde, glabro; limbo orbicular a oval, $2,5-10 \times 2,3-9,5 \mathrm{~cm}$, verde, acródromo, glabro, ápice obtuso a arredondado, raramente retuso, base atenuada a truncada; lígula membranácea a foliácea, $4-5 \mathrm{~cm}$ compr., esverdeada a vinácea, ápice foliáceo. Eixo reprodutivo 10-20 cm compr. Bráctea reduzida, limbo oval, 1-3 $\times 0,9$ $2,4 \mathrm{~cm}$. Tirso espiciforme, 5-10-flora; pedúnculo 1,5-2 cm compr.; bractéola oboval, cimbiforme, 3-6 cm compr., ápice mucronado; raque 5,6-8 cm compr., pubérula. Flores com face externa pubérula; lobos externos com margem inteira, 20-25 mm compr., 1 anterior e 2 laterais posteriores elípticos a obovais, lobos internos com margem inteira, 22-29 $\mathrm{mm}$ compr., 1 posterior largo-elíptico, lilás com guia de néctar e 2 posteriores obovais, lilases; estames 6 , filetes 5-20 mm compr., lilases, pubérulos; anteras elípticas a oblongas, ca. 1,8 mm compr., azuladas; ovário ca. $3 \mathrm{~mm}$ compr., esverdeado, glabro; estilete 20-30 mm compr., azulado com porção apical lilás, pubérulo no ápice; estigma trilobado, branco. Cápsula e sementes não vistas.

Material selecionado: Fortaleza, Lagoa da Parangaba, ambiente aquático, 26.V.2009, A.B. Tabosa (EAC 45502). Icó, Açude Lima Campos, 28.VI.1937, P. Luetzelburg 28621 (EAC). Iguatu, Açude Orós, Santarém, 5.IX.2009, L.Q. Matias 589 (EAC). Varjota, Açude Araras, 30.VI.2010, J.R.A. Paiva 4 (EAC).

Eichhornia crassipes possui registros para os continentes asiático, africano e americano (Schulz 1942; Castellanos 1958; Kuo-fang \& Horn 2000), com ocorrência para todas as regiões do Brasil (BFG
2015; Sousa 2017). No Ceará, foram observadas populações desde a região noroeste até a região sul do estado (Fig. 1, quadrículas B3, B6, C3, F3, F4, F5, G4, G5). Eichhornia crassipes apresenta como principal caráter diagnóstico seus pecíolos inflados, característica relacionada diretamente à forma de crescimento flutuante livre, podendo alcançar as margens dos corpos d'água e se fixar. Além disso, as folhas são basais e as brácteas são reduzidas quando comparadas com as demais folhas, além dos pedúnculos das inflorescências que também possuem pequenas dimensões. Estas características facilitam o reconhecimento da espécie mesmo quando herborizada.

1.2. Eichhornia diversifolia (Vahl) Urban. Symb. Antill. 4: 147. 1903. Figs. 2c-e; 4b

Erva flutuante fixa, $15-30 \mathrm{~cm}$ alt. Folha flutuante, alterna, dística, ao longo do caule; pecíolo nunca inflado, ca. $6,5 \times 0,2 \mathrm{~cm}$, vináceo, glabro; limbo arredondado a oval, 1,4-3,3 × 1,5-3 cm, face adaxial verde, face abaxial vinácea, acródromo a campilódromo, glabro, ápice obtuso a arredondado, base cordada; Folha submersa membranácea linear, lígula membranácea a foliácea, $2,5-3 \mathrm{~cm}$ compr., hialina a vinácea, ápice truncado. Eixo reprodutivo 0,5-2 cm compr. Bráctea semelhante às folhas. Cimeira (2-)3-flora; pedúnculo 0,8-1,2 cm compr.; bractérola estreito oboval, cimbiforme, $1,5-2 \mathrm{~cm}$ compr., ápice obtuso, levemente retuso, mucronado; raque 2,2-2,8 cm compr., pubérula. Flores com face externa do tubo do perigônio pubérula; lobos externos com margem inteira, ca. $10 \mathrm{~mm}$ compr., 1 posterior e 2 anteriores largo elípticos, lobos internos com margem inteira, ca. $13 \mathrm{~mm}$ compr., 1 anterior oboval, lilás com mácula amarela mediana 


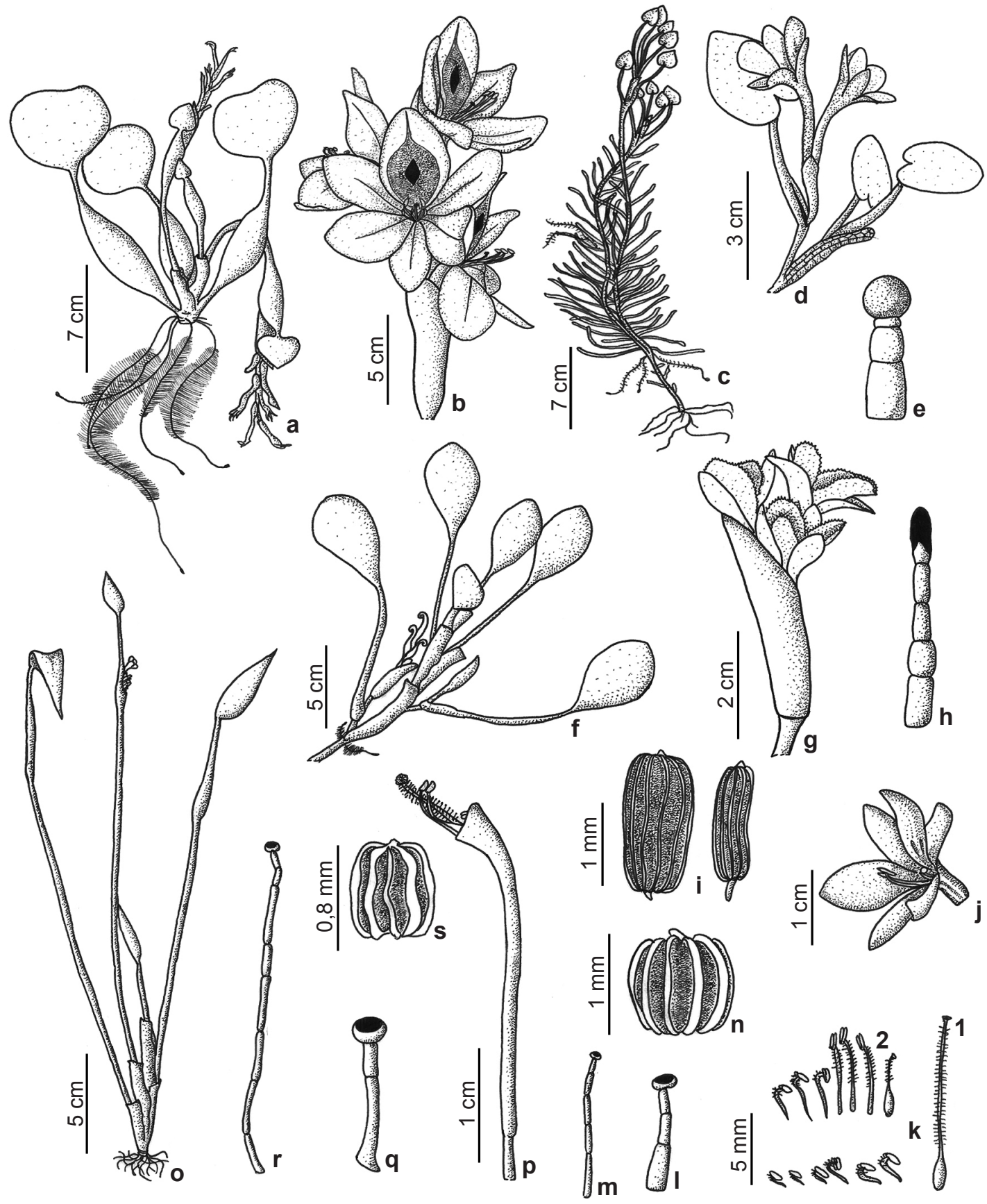

Figura 2 -a,b. Eichhornia crassipes - a. hábito; b. inflorescência. c-e. Eichhornia diversifolia - c. hábito; d. eixo reprodutivo; e. tricoma do tubo do perigônio. f-i. Eichhornia heterosperma - f. hábito; g. inflorescência; h. tricoma do tubo da flor; i. semente. j-n. Eichhornia paniculata - j. flor; k. androceu e gineceu (1. flor longistila; 2. flor medistila); 1. tricoma do tubo da flor; m. tricoma do estilete; n. semente. o-s. Eichhornia paradoxa - o. hábito; p. detalhe da flor com os lobos destacados; q. tricoma do filete; r. tricoma do estilete; s. semente. (a,b. A.B. Tabosa EAC-45502; c-e. L.Q. Matias 627; f-h. L.Q. Matias 619; i. L.R.O. Normando 454; j,k1,1-n. D.J.L. Sousa 98; k2. A.B. Tabosa 2; o-s. L.Q. Matias 713).

Figure 2 - a,b. Eichhornia crassipes - a. habit; b. inflorescence. c-e. Eichhornia diversifolia - c. habit; d. reproductive axis; e. trichome of the floral tube. f-i. Eichhornia heterosperma - f. habit; g. inflorescence; h. trichome of the floral tube; i. seeds. j-n. Eichhornia paniculata - j. flower; $\mathrm{k}$. androecium and gynoecium (1. longistylous flower; 2 . medistylous flower); 1 . trichome of the flower tube; $\mathrm{m}$. trichome of the style; $\mathrm{n}$. seed. o-s. Eichhornia paradoxa-o. habit; p. flower detail with the lobes removed; q. trichome of the filament; $r$ trichome of the style; s. seed. (a,b. A.B. Tabosa EAC-45502; c-e. L.Q. Matias 627; f-h. L.Q. Matias 619; i. L.R.O. Normando 454; j,k1,1-n. D.J.L. Sousa 98; k2.A.B. Tabosa 2; o-s. L.Q. Matias 713). 
e 2 posteriores obovais, lilases; estames 6 , filetes 3-6 mm compr., azulados, glabros; anteras elípticas a sagitadas, 1,3 mm compr., azuladas; ovário ca. $4 \mathrm{~mm}$ compr., vináceo, glabro; estilete ca. $19 \mathrm{~mm}$ compr., azulado com porção apical lilás, glabro; estigma capitado, branco. Cápsula ca. $16 \mathrm{~mm}$ compr. Sementes homomorfas, elipsoides, 0,5-1 mm compr.

Material selecionado: Caridade, Lagoa das Contendas, 5.VIII.2009, D.J.L. Sousa 99 (EAC). Caucaia, Praíba, Riacho dos Matões, 1.V.2009, A.S.F. Castro 2161 (EAC). Crateús, lagoa em estrada para a Serra das Almas, 25.VI.2003, L.Q. Matias 459 (EAC). Fortaleza, Barra do Ceará, 26.IX.1935, F.E. Drouet 2514 (NY). Granja, Olho D'água do Costa, 18.VII.2003, L.Q. Matias 486 (EAC).

Eichhornia diversifolia apresenta uma distribuição americana, principalmente na América do Sul (Castellanos 1958; Crow 2003). No Brasil, apresenta ocorrência mais restrita na Região Sudeste (Minas Gerais), mas ampla distribuição no CentroOeste, Norte e Nordeste (BFG 2015; Sousa 2017). No Ceará, nota-se a ocorrência de populações da espécie mais concentrada na região noroeste do estado (Fig. 1, quadrículas A2, A3, A4, B2, B3, B5, B6, C5, D2, D3). Esta espécie pode ser facilmente reconhecida por serem plantas diminutas prostradas na lâmina d'água e com folhas cordiformes, sendo as únicas no gênero com esse padrão. Além disso, apresentam inflorescências com poucas flores (2-3). Apesar disto, alguns exemplares nas coleções encontravam-se identificados como Heteranthera reniformis Ruiz \& Pav., que pode ser distinta de $E$. diversifolia, entre outros caracteres, pelo número de estames (três em $H$. reniformis vs. seis estames em $E$. diversifolia).

1.3. Eichhornia heterosperma Alexander, Lloydia 2: 170.1939

Figs. 2f-i; 4c,d

Erva emergente, decumbente, $20-30 \mathrm{~cm}$ alt. Folha emersa, alterna, dística, ao longo do caule; pecíolo nunca inflado, $13-18 \times 0,3-0,4 \mathrm{~cm}$, verde a vináceo, glabro a pubérulo; limbo oboval, raramente arredondado, ca. 6,5 × 3,5-5 cm, verde, acródromo, glabro, ápice obtuso a arredondado, base atenuada; lígula membranácea a foliácea, 6-7,5 cm compr., vinácea, ápice truncado. Eixo reprodutivo 1,5-2 cm compr. Bráctea semelhante às folhas. Tirso espiciforme 7-11-flora; pedúnculo 0,8-2 cm compr.; bractéola oboval, cimbiforme, 3,5-4,5 cm compr., ápice obtuso, levemente retuso, não mucronado; raque 2,5-4,5 cm compr., glabra. Flores com face externa do tubo do perigônio pubérula; lobos externos com margem inteira, 12-14 mm compr., 1 posterior e 2 anteriores elípticos, lobos internos com margem erosa, 13-16 mm compr., 1 anterior largo elíptico a oboval, lilás com base azulada, mácula ausente e 2 posteriores largo elípticos, lilases; estames 6 , filetes $2-10 \mathrm{~mm}$ compr.; anteras sagitadas, 1-1,4 mm compr., azuladas ou amareladas; ovário 4-5 mm compr., esverdeado com ápice levemente vináceo, glabro; estilete 7-15 mm compr., esbranquiçado com ápice lilás, glabro; estigma capitado, lilás. Cápsula ca. $13 \mathrm{~mm}$ compr. Sementes heteromorfas, elipsoides ou oblongas, 1-2 mm compr.

Material selecionado: Caucaia, Tucunduba, 10.IX.2006, A.S.F. Castro 2111 (EAC). Crateús, lagoa em beira de estrada para a Serra das Almas, 25.VI.2003, L.Q. Matias 456 (EAC). Fortaleza, Lagoa Piauí, Messejana, 24.X.1935, F.E. Drouet 2649 (MO). Granja, 18.VII.2003, L.Q. Matias 482 (EAC). Iguatu, lagoa temporária em Mocó/Lajes, 16.V.2010, L.R.O. Normando 300 (EAC). Maranguape, Açude São Bento, 5.VIII.1935, F.E. Drouet 2179 (NY).

Eichhornia heterosperma possui registros de ocorrência desde o México até o Brasil, sendo citada para as regiões Sudeste (Minas Gerais), Norte (Acre, Pará, Rondônia, Roraima) e para todo o Nordeste do país (Novelo \& Ramos 1998; Crow 2003; BFG 2015; Sousa 2017). No Ceará, as populações ocorrem em áreas alagáveis no noroeste do estado e nas lagoas temporárias no semiárido (Fig. 1, quadrículas A2, B2, B4, B5, C3, D2, D3, F3, F5). Muitas vezes confundida com Eichhornia azurea (Sw.) Kunth (sem registro para o Ceará), E. heterosperma apresenta como principal diferença os filetes glabros (em contraste com os filetes pubescentes de E. azurea) (Alexander 1939; Sousa \& Giulietti 2014; Sousa et al. 2016b). Os espécimes possuem entrenós alongados e folhas emersas, distribuídas no decorrer do caule. Suas inflorescências apresentam raque glabra e inserida na bráctea. As flores são delicadas, geralmente lilases, sendo que no Ceará são encontradas as únicas populações até então descritas com flores alvas para o país.

1.4. Eichhornia paniculata (Spreng.) Solms., Monogr. Phan. 4: 530. 1883 . Figs. 2j-n; 4e

Erva emergente, ereta, 25-60 cm alt. Folha emersa, alterna, espiralada, basal; pecíolo nunca inflado, $19-40 \times 0,2-0,8 \mathrm{~cm}$, verde, glabro; limbo largo oval a amplo lanceolado, 7,5-26 × 3-23,5 cm, verde, campilódromo, glabro, ápice agudo raramente obtuso, base cordada; lígula membranácea, ca. $9 \mathrm{~cm}$ compr., hialina a esverdeada, ápice truncado. Eixo reprodutivo $20-45 \mathrm{~cm}$ compr. Bráctea semelhante às folhas. Tirso paniculado 30-180-floro; pedúnculo 
2-3 cm compr.; bráctea triangular, $2-7 \mathrm{~cm}$ compr., ápice agudo, mucronado; raque 10-25 cm compr., pubérula. Flores com face do tubo do perigônio pubérula; lobos externos com margem inteira, ca. $14 \mathrm{~mm}$ compr., 1 posterior e 2 laterais anteriores elípticos, lobos internos com margem inteira, ca. 16 mm compr., 1 anterior largo elíptico a oboval, lilás com duas máculas amarelas e 2 posteriores largo elípticos a obovais, lilases; estames 6 , filetes 1-10 $\mathrm{mm}$ compr., lilases, pubescentes; anteras elípticas a sagitadas, ca. $13 \mathrm{~mm}$ compr., azuladas; ovário ca. $6 \mathrm{~mm}$ compr., verde, glabro; estilete $3-13 \mathrm{~mm}$ compr., vináceo, piloso; estigma capitado, branco. Cápsula ca. $10 \mathrm{~mm}$ compr. Sementes homomorfas, arredondadas, ca. $1 \mathrm{~mm}$ compr.

Material selecionado: Baturité, 6.IX.1997, L.Q. Matias 70 (EAC). Caridade, Fazenda Palestina, Lagoa das Contendas, 20.III.2008, A.B. Tabosa 1 (EAC). Caucaia, Parque Botânico de Caucaia, 17.IV.1998, L.Q. Matias 68 (EAC). Fortaleza, Alagadiço São Gerardo, 10.V.1941, $P$. Bezerra (EAC787). Itapagé, BR-222, km 145, 30.V.1979, E. Nunes (EAC6212). Maranguape, Açude São Bento, 5.VIII.1935, F.E. Drouet 2176 (NY). Meruoca, Sítio Santo Antônio, Serra da Meruoca, 10.VII.1961, A. Fernandes (EAC2113). Missão Velha, Ponte do Rio, 15.VII.2003, L.Q. Matias 419 (HUEFS 80793). Pacoti, Sítio Pirajá, Serra de Baturité, 12.XII.1940, B. Landim 26 (EAC).

Eichhornia paniculata apresenta ocorrência nas Américas Central e do Sul (Schulz 1942; Castellanos 1958; Novelo \& Ramos 1998; Crow 2003) e, no Brasil, na Região Nordeste (BFG 2015; Sousa 2017). No Ceará, o predomínio das populações existe no noroeste do estado (Fig. 1, quadrículas B3, B4, B5, B6, C5, D3, G5). A espécie compartilha com Eichhornia paradoxa (Schult. f. ex Mart.) Solms a forma de crescimento emergente e as folhas basais com pecíolos e eixos reprodutivos compridos. Entretanto, E. paniculata possui numerosas flores agrupadas em tirsos paniculados bem desenvolvidos e folhas com limbos cordiformes (contrastado aos cincinos com apenas uma flor aberta por vez e folhas estreitas em E. paradoxa).

1.5. Eichhornia paradoxa (Schult. f. ex Mart.) Solms., Monogr. Phan. 4: 531. 1883.

Figs. 2o-s; 4f,g

Erva emergente, ereta, $22-27 \mathrm{~cm}$ alt. Folha emersa, alterna, espiralada, basal; pecíolo nunca inflado, 14-23 × 0,2-0,3 cm, verde, glabro; limbo estreito elíptico a estreito lanceolado, 3,2-4,8 $\times$ 0,4-0,9 cm, verde, paralelódromo a acródromo, glabro, ápice agudo a obtuso, base atenuada; lígula membranácea, ca. 2 cm compr., esverdeada a vinácea, ápice truncado. Eixo reprodutivo 16-25 $\mathrm{cm}$ compr. Bráctea semelhante às folhas. Cincino 3-4-flora; pedúnculo ausente; bractéola ausente; raque ausente. Flores com face externa do tubo do perigônio glabra; lobos externos com margem inteira, ca. $13 \mathrm{~mm}$ compr., 1 posterior e 2 anteriores elípticos a lanceolados, lobos internos com margem inteira, ca. $15 \mathrm{~mm}$ compr., 1 anterior largo elíptico, lilás com duas máculas amarelas na base e 2 posteriores largo elípticos, lilases; estames 6 , filetes 1-4 mm compr., brancos, ápice lilás, pubérulos; anteras obovadas a elípticas, ca. $1 \mathrm{~mm}$ compr., amarelas; ovário ca. $5 \mathrm{~mm}$ compr., verde, glabro; estilete ca. $25 \mathrm{~mm}$ compr., esverdeado com porção apical lilás, viloso; estigma trilobado, branco. Cápsula ca. $13 \mathrm{~mm}$ compr. Sementes homomorfas, arredondadas a levemente elipsoides, $0,9-1,3 \mathrm{~mm}$ compr.

Material examinado: Caridade, Fazenda Palestina, Lagoa das Contendas, 24.V.2014, L. Q. Matias 713 (EAC).

Eichhornia paradoxa ocorre desde a Guatemala até o Brasil (Castellanos 1958; Crow 2003). No Brasil, a espécie possui registros para os estados da Bahia, Pará e Rio Grande do Norte (BFG 2015; Sousa 2017), sendo neste trabalho ampliada a sua distribuição, reportada a nova ocorrência para o Ceará (Fig. 1, quadrícula C5). De fácil identificação, $E$. paradoxa é a única espécie emergente com folhas estreitas do gênero. Além disso, dentre as Pontederiaceae, é a única espécie com inflorescências em cincinos, apresentando apenas uma flor em antese por dia.

2. Heteranthera Ruiz \& Pav., Fl. Peruv. Prodr. 9. 1794.

Ervas emergentes, flutuantes fixas ou submersas. Folhas alternas, dísticas ou espiraladas, ao longo do caule, submersas, emersas ou flutuantes, sésseis ou pecioladas; pecíolos não inflados, cilíndricos; limbos filiformes ou oblongos a reniformes; ápice acuminado a arredondado; base cordada, atenuada ou arredondada a truncada. Eixo reprodutivo curto. Bráctea semelhante às folhas. Inflorescências em cimeiras 2-, 14-floras ou reduzidas a uma flor; bractéola fechada, cimbiforme, oboval; raque glabra ou pubescente. Flores lilases, brancas ou amarelas, tubo do perigônio com face externa glabra ou pubescente; lobos externos com margem inteira, elípticos, lobos internos com margem inteira, elípticos a ovais, $(3+3$ ou 5+1), lobo mediano posterior com guia de néctar; estames 3 , raramente 1 mais 2 estaminódios, filetes 
cilíndrico ou achatados, brancos a azulados ou amarelos, glabros, pubescentes ou vilosos, anteras heteromorfas, elípticas a sagitadas, basifixas a dorsifixas, azuladas ou amarelas; ovário verde a amarelo, glabro, trilocular, lóculos todos férteis, multiovulados, estilete branco, lilás ou amarelado, glabro, pubescente ou papiloso, estigma capitado a lobado, azulado, esbranquiçado ou amarelado. Cápsula loculicida esverdeada; antocarpo castanho a engrecido ou esverdeado, não torcido no ápice, liso, não alado. Sementes elipsoides a subglobosas, costadas.

As espécies de Heteranthera apresentam flores pequenas, geralmente em cimeiras simples.
$\mathrm{O}$ androceu possui as principais características distintivas do gênero, como a presença de três estames e as anteras heteromórficas. O gênero vem sendo indicado como parafilético nas análises filogenéticas, porém tornando-se monofilético com a inserção de Hydrothrix gardneri Hook.f. (Ness et al. 2011), o que pode dificultar a delimitação morfológica do grupo formado pela junção das espécies dos dois gêneros. Heteranthera apresenta ocorrência nas regiões tropicais e subtropicais dos continentes Americanos e Africano (Horn 1985). No Brasil, podem ser encontradas espécies do gênero em todas as regiões (BFG 2015; Sousa 2017) e, para o Ceará, são apresentadas três espécies.

\section{Chave de identificação das espécies de Heteranthera do Ceará}

1. Folhas lineares, sésseis; cimeira 7-10-flora; bractéola com ápice aristado; flores amarelas .....

2.3. Heteranthera seubertiana

1'. Folhas ovais, arredondadas, raramente cordiformes, pecioladas; cimeira 2-flora ou flores solitárias; bractéola com ápice mucronado; flores lilases ou brancas

2. Flores solitárias; bractéola elíptica a lanceolada, ápice agudo; tubo do perigônio externamente glabro 2.2. Heteranthera rotundifolia

2'. Inflorescências 2-floras; bractéola oboval, ápice obtuso, levemente retuso; tubo do perigônio externamente pubérulo. 2.1. Heteranthera oblongifolia

2.1. Heteranthera oblongifolia Mart. ex Schult. \& Schult. f., Syst. Veg. 7: 1148. 1830.

Figs. 3a-d; 4h,i

Erva emergente, decumbente ou ereta, 13-21 $\mathrm{cm}$ alt. Folha emersa, alterna, dística, ao longo do caule; pecíolo nunca inflado, 6-15 × 0,2-0,3 cm, verde, glabro; limbo largo elíptico a oval, 2,3-5 $\times$ 1-4,5 cm, verde, acródromo a campilódromo, glabro, ápice agudo ou obtuso, base arredondada a cordada; lígula membranácea, 3-5 cm compr., vinácea, ápice truncado a levemente retuso. Eixo reprodutivo 1,5-3 $\mathrm{cm}$ compr. Bráctea semelhante às folhas. Cimeira 2-flora; pedúnculo 2,5-3 cm compr.; bractéola oboval, cimbiforme, 1,8-2,9 cm compr., ápice obtuso, levemente retuso, mucronado; raque ca. $1 \mathrm{~cm}$ compr., glabra. Flores com face externa do tubo do perigônio pubérula; lobos externos ca. $6 \mathrm{~mm}$ compr., 1 posterior e 2 anteriores elípticos a largo elípticos, brancos ou lilases, lobos internos ca. $7 \mathrm{~mm}$ compr., 1 anterior largo elíptico, branco ou lilás com mácula amarela na base e 2 posteriores elípticos a largo elípticos (3+3), brancos ou lilases; estames 3, 1 maior e 2 menores, filetes 2-3 mm compr., branco ou levemente lilás, pubérulo; antera oblonga, maior ca. $3 \mathrm{~mm}$ compr. e menores ca. $2 \mathrm{~mm}$ compr., amarelas; ovário ca. $6 \mathrm{~mm}$ compr., esverdeado, glabro; estilete ca. 7,2 mm compr., esverdeado ou levemente lilás, pubérulo; estigma capitado, branco. Cápsula 15-17 mm compr. Sementes oblongas, ca. $0,8 \mathrm{~mm}$ compr. Material selecionado: Aiuaba, Estação Ecológica, Açude Normando, 19.V.2003, L.Q. Matias 431 (EAC). Caridade, Lagoa Contendas, 21.VI.2008, D.J.L. Sousa 1 (EAC). Caucaia, Santa Bárbara próximo a Pinhões, 21.IV.2002, A.S.F. Castro 1187 (EAC). Crateús, estrada para Serra das Almas, 25.VI.2003, L.Q. Matias 470 (EAC). Jati, Fazenda Queimadas, 4.V.2003, L.Q. Matias 380 (EAC). Quixadá, Açude Boa Água, 2.IX.1935, F.E. Drouet 2414 (RB). Santa Quitéria, Monte Alegre, estrada para Tamboril, 22.VI.2011, A.S.F. Castro 2504 (EAC).

Heteranthera oblongifolia ocorre nas Américas, incluindo as Ilhas Caribenhas (Horn 1985; Novelo \& Ramos 1998; Crow 2003). No Brasil, a espécie é citada para a Região Sudeste (Minas Gerais) e para os estados do Nordeste (BFG 2015; Sousa 2017). No Ceará, apresenta ampla ocorrência (Fig. 1, quadrículas B5, C3, C5, D2, D5, E3, E5, E6, F3, H5). Heteranthera oblongifolia apresenta inflorescências bifloras, podendo ambas flores abrirem simultaneamente ou não. Desta forma, existe o erro comum de caracterizar os espécimes depositados em coleções como possuindo flores 

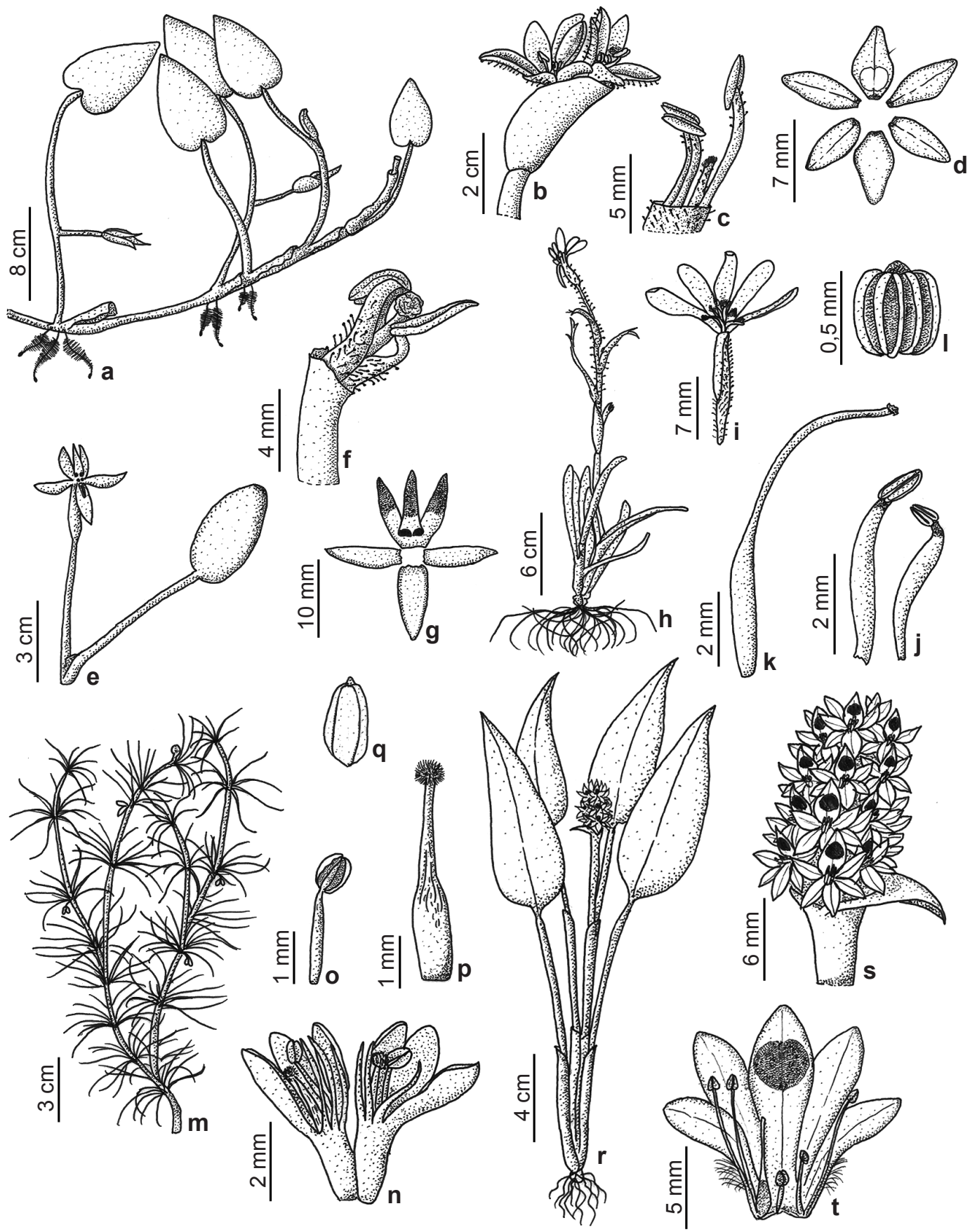

Figura 3 -a-d. Heteranthera oblongifolia - a. hábito; b. inflorescência; c. detalhe da porção apical da flor com os lobos destacados; d. lobos. e-g. Heteranthera rotundifolia - e. hábito; f. detalhe da porção apical da flor com os lobos destacados; g. lobos. h-l. Heteranthera seubertiana - h. hábito; i. flor; j. androceu; k. gineceu; 1 . semente. m-q. Hydrothrix gardneri-m. hábito; n. flores; o. androceu; p. gineceu; q. semente. r-t. Pontederia parviflora - r. hábito; s. detalhe da inflorescência; t. flor dissecada. (a-d. D.J.L. Sousa 19; e-g. L.Q. Matias 714; h-1. L.Q. Matias 471; m. V.M. Cotarelli 1828; n-q. M.F. Moro 477; r-t. A.S.F. Castro 1082).

Figure 3 - a-d. Heteranthera oblongifolia - a. habit; b. inflorescence; c. apical portion of the flower detail with the lobes removed; d. lobos. e-g. Heteranthera rotundifolia - e. habit; f. apical portion of the flower detail with the lobes removed; g. lobes. h-l. Heteranthera seubertiana $-\mathrm{h}$. habit; i. flower; . androecium; k. gynoecium; 1 . seed. $\mathrm{m}$-q. Hydrothrix gardneri - $\mathrm{m}$. habit; $\mathrm{n}$. flower; o. androecium; p. gynoecium; q. seed; $\mathrm{r}$-t. Pontederia parviflora - r. habit; s. inflorescence detail; t. dissected flower. (a-d. D.J.L. Sousa 19; e-g. L.Q. Matias 714; h-1. L.Q. Matias 471; m. V.M. Cotarelli 1828; n-q. M.F. Moro 477; r-t. A.S.F. Castro 1082). 
solitárias e, desta forma, identificar tais amostras como H. rotundifolia (Kunth) Griseb. ou H. limosa (Sw.) Willd. Neste caso, a observação da presença da segunda flor, que possa provavelmente estar em estágio de botão no interior da bractéola, torna-se fundamental para o diagnóstico. Além disso, as bractéolas são obovais e bem mais amplas que as bractéolas das espécies unifloras.
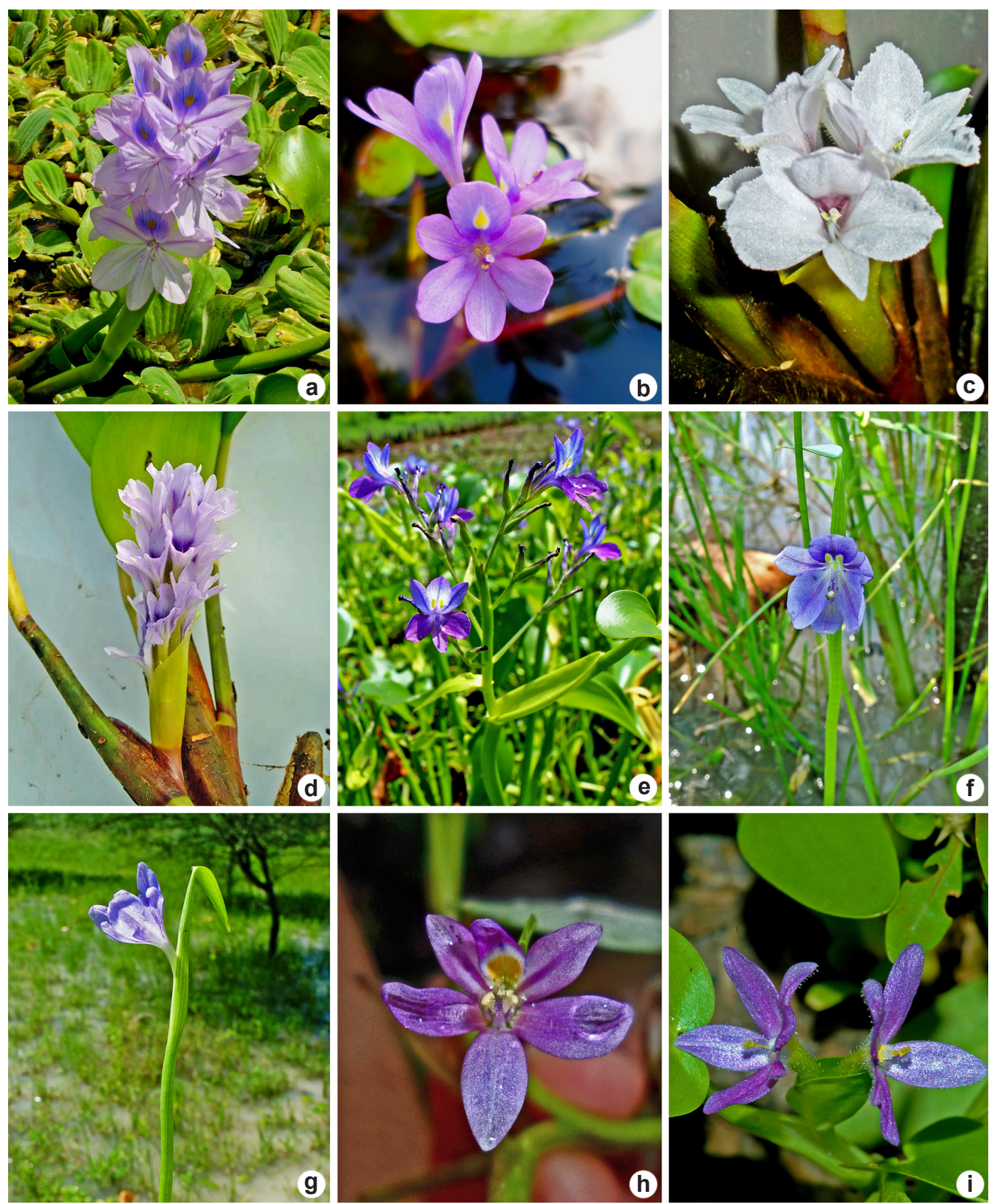

Figura 4 - a. Eichhornia crassipes; b. Eichhornia diversifolia; c,d. Eichhornia heterosperma; e. Eichhornia paniculata; f,g. Eichhornia paradoxa; h,i. Heteranthera oblongifolia.

Figure 4 - a. Eichhornia crassipes; b. Eichhornia diversifolia; c,d. Eichhornia heterosperma; e. Eichhornia paniculata; f,g. Eichhornia paradoxa; h,i. Heteranthera oblongifolia. 
2.2. Heteranthera rotundifolia (Kunth) Griseb., Cat. Pl. Cub. 252. 1866. Figs. 3e-g; 5a

Erva emergente ou flutuante fixa, ereta ou decumbente, 9-15 cm alt. Folha emersa, ou flutuante, alterna, dística, basal ou ao longo do caule; pecíolo nunca inflado, $5-7 \times 0,1-0,2 \mathrm{~cm}$, verde, glabro; limbo largo elíptico a arredondado, 1,3-3 × 1,4-1,5 cm, verde, acródromo, glabro, ápice obtuso a arredondado, base truncada a arredondada; lígula, membranácea, ca. 2,5 cm compr., hialina, ápice truncado. Eixo reprodutivo 1-3 cm compr. Bráctea semelhante às folhas. Flores solitárias; pedúnculo 2,5-3 cm compr.; bractéola elíptica a lanceolada, cimbiforme, 1,5-2 cm compr., ápice agudo, mucronado; raque ausente; face externa do tubo do perigônio glabra; lobos externos ca. 11-13 $\mathrm{mm}$ compr., 1 posterior largo elíptico, brancos ou lilases e 2 anteriores elípticos, brancos ou lilases, patentes, lobos internos ca. $11 \mathrm{~mm}$ compr., 1 anterior triangular, com duas projeções lilases na base, branco ou lilás e 2 laterais horizontais elípticos $(3+2+1)$, brancos ou lilases; estames 3,1 maior e 2 menores, filetes 4-5 mm compr., azulados ou brancos, pubérulos; antera sagitada, maior ca. 4,5 mm compr. e menor ca. $3,8 \mathrm{~mm}$ compr., amarela; ovário ca. $8 \mathrm{~mm}$ compr., esverdeado, glabro; estilete ca. $12 \mathrm{~mm}$ compr., azulado, glabro; estigma trilobado, azulado ou esbranquiçado. Cápsula ca. $15 \mathrm{~mm}$ compr. Sementes oblongas a ovadas, ca. $0,9 \mathrm{~mm}$ compr.

Material examinado: Caridade, lagoa contendas, 24.V.2014, L.Q. Matias 714 (EAC). Jaguaribe, Maciço do Pereiro, 10.IV.2011, A.M. Miranda \& K. Manso 6269 (EAC).

Heteranthera rotundifolia está distribuída pela região tropical e subtropical das Américas (Horn 1985; Novelo \& Ramos 1998; Crow 2003) e, no Brasil, ocorre em todos estados nordestinos (BFG 2015; Sousa 2017). No Ceará, dois registros existem para a região semiárida do Estado (Fig. 1, quadrícula E6). Heteranthera rotundifolia compartilha com $H$. limosa (Sw.) Willd. (sem registros para o Ceará) caracteres como a forma de crescimento e as flores solitárias, sendo frequentemente confundidas nas coleções botânicas. Entretanto, H. rotundifolia apresenta a disposição dos lobos florais bem distintos, onde são encontrados três lobos posteriores (laterais patentes e o central triangular), dois lobos horizontais e um lobo anterior mais amplo que os demais (contrastando com os três lobos posteriores e os três lobos anteriores, de dimensões semelhantes presentes nos indivíduos de $H$. limosa). Além disso, o lobo mediando posterior de $H$. rotundifolia apresenta duas projeções basais, ausentes em $H$. limosa (Horn 1985; Sousa \& Giulietti 2014).

2.3. Heteranthera seubertiana Solms, Monogr. Phan. 4: 518. 1882. Figs. 3h-1; 5b

Erva submersa ou emergente, ereta, 15-30 $\mathrm{cm}$ alt. Folha submersa ou emergente, alterna, ao longo do caule quando submersa, ou basal quando emergente, séssil; limbo linear, 9-16 × 0,4-1,3 cm, verde, paralelódromo, glabro, quando emergente com poucos tricomas, ápice acuminado, base truncada; lígula membranácea, ca. 1,5 cm compr., esverdeada, ápice truncado a acuminado. Eixo reprodutivo 1-2 cm compr. Bráctea semelhante às folhas. Cimeira 7-10-flora; pedúnculo ca. 3,5 cm compr.; bractéola largo elíptica, cimbiforme, ca. 3,3 cm compr., ápice aristado; raque ca. 0,6 cm compr., pubérula. Flores com face externa do tubo do perigônio pubérula; lobos externos ca. 7 $\mathrm{mm}$ compr., 1 posterior elíptico a linear, amarelo a esverdeado e 2 anteriores estreito-obovais, amarelos, com base vinácea, lobos internos ca. 7,5 mm compr., 1 anterior e 2 anteriores elípticos $(5+1)$, amarelos com base vinácea; estames 3, 1 maior e 2 menores, filetes $1-4 \mathrm{~mm}$ compr., amarelos, glabros; anteras oblongas, maior ca. $1 \mathrm{~mm}$ compr. e menores ca. $0,5 \mathrm{~mm}$ compr., amarelas; ovário ca. $4 \mathrm{~mm}$ compr., amarelado, glabro; estilete ca. 7 mm compr., amarelado, glabro a pubérulo; estigma capitado, amarelado. Cápsula ca. $10 \mathrm{~mm}$ compr. Sementes elipsoides a subglobosas, ca. $0,5 \mathrm{~mm}$ compr.

Material examinado: Sem localidade, 1838, G. Gardner 1864 (G). Aiuaba, Estação Ecológica, Açude Tamanduá, 26.VI.2003, L.Q. Matias 471 (EAC). Jucás, próximo à ponte sobre o Rio Jaguaribe, 5.IV.2000, F.S. Cavalcanti (EAC29991).

Heteranthera seubertiana apresenta registros para México, Venezuela e Brasil (Horn 1985; Novelo \& Ramos 1998). Em território brasileiro, a ocorrência da espécie é indicada para a Região Nordeste, nos estados de Alagoas, Bahia, Paraíba, Pernambuco, Rio Grande do Norte, Sergipe e Ceará (BFG 2015; Sousa 2017). No Ceará, as populações ocorreram em mananciais do semiárido (Fig. 1, quadrículas E5, F3, F4). A descrição da espécie foi baseada principalmente em um espécime coletado por Gardner ( $\left.{ }^{\circ} 1864\right)$ em 1838, em sua passagem pelo estado do Ceará. Ela é distinta por suas folhas sésseis e filiformes que podem ser basais (nos indivíduos emergentes) ou distribuídas pelo caule (nos indivíduos submersos); e suas flores amarelas apresentando cinco lobos anteriores e um lobo posterior. 
3. Hydrothrix Hook. f., Ann. Bot. (Oxford) 1: 89. 1887.

Ervas submersas fixas. Folhas verticiladas, ao longo do caule, submersas, sésseis; limbos lineares. Eixo reprodutivo curto. Bráctea semelhante às folhas. Inflorescências 2-floras, imitando uma única flor (pseudanto); bractéola oboval, tubulosa, fechada; raque ausente. Flores amarelas, tubo do perigônio com face externa glabra; lobos externos com margem inteira, amplo elípticos a ovais, lobos
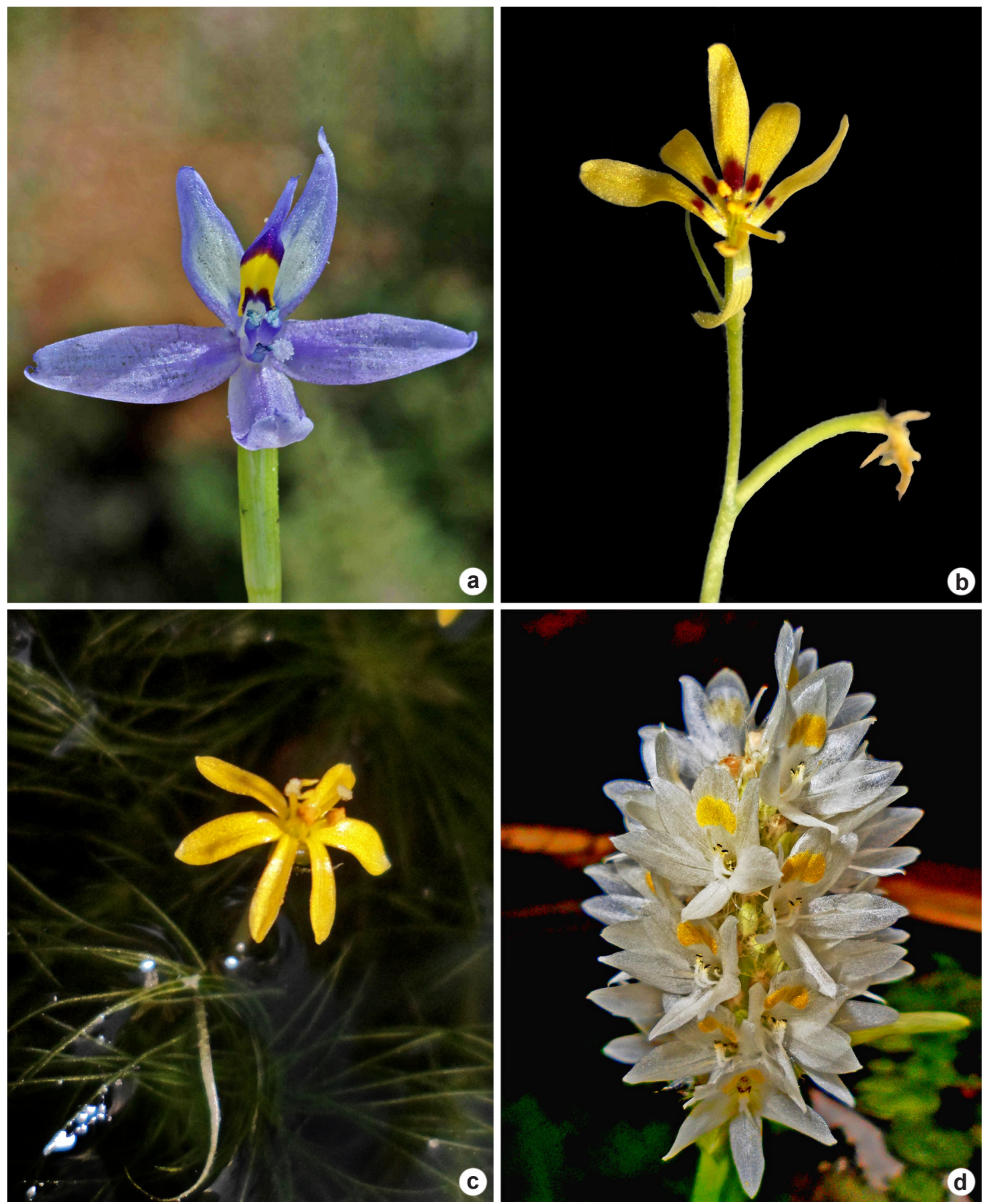

Figura 5 - a. Heteranthera rotundifolia; b. Heteranthera seubertiana; c. Hydrothrix gardneri; d. Pontederia parviflora. Figure 5 - a. Heteranthera rotundifolia; b. Heteranthera seubertiana; c. Hydrothrix gardneri; d. Pontederia parviflora. 
internos com margem inteira, lineares a obovais $(3+3)$, lobo mediano anterior sem guia de néctar; estame 1, filete cilíndrico, amarelo, glabro, antera oblonga, basifixa, amarela; estaminódios ausentes, ovário verde, glabro, trilocular, lóculos todos férteis, multiovulados, estilete amarelo, glabro, estigma capitado, branco. Cápsula esverdeada a pardacenta, antocarpo ausente. Sementes elipsoides, costadas, às vezes lisas.

Hydrothrix é um gênero monoespecífico e endêmico da região semiárida do Brasil (Hooker 1887; BGF 2015; Sousa 2017), sendo representado no Ceará pela sua única espécie, $H$. gardneri Hook. f.

3.1. Hydrothrix gardneri Hook. f., Ann. Bot. 1: 90. 1887.

Figs. 3m-q; $5 \mathrm{c}$

Erva submersa, 13-27 cm alt. Folha submersa, verticilada, ao longo do caule, séssil; limbo linear, 2-4 × 0,05 cm, verde, estriado, glabro; lígula membranácea, ca. 0,4 cm compr., hialina a castanho, ápice eroso. Eixo reprodutivo 0,8-1,5 cm compr. Bráctea semelhante às folhas. Inflorescência 2-flora; pedúnculo ca. $1 \mathrm{~cm}$ compr., esverdeado; bractéola tubulosa, ca. 0,6 mm compr., ápice bífido, retuso, glabra. Flores com face externa do tubo do perigônio glabra; lobos externos ca. 2,5 mm compr., 1 posterior amplo elíptico a oval e 2 anteriores lineares, amarelos, lobos internos ca. $2 \mathrm{~mm}$ compr., 1 anterior linear, amarelo, mácula ausente e 2 posteriores amplo elípticos a ovais $(3+3)$, amarelos; estame 1 , filete ca. $2 \mathrm{~mm}$ compr., amarelo, glabro; antera oblonga, ca. 0,8 mm compr., amarela; ovário ca. 1,5 mm compr., esverdeado com estrias vináceas no ápice, glabro; estilete ca. 2 mm compr., amarelo, glabro; estigma capitado, branco. Cápsula ca. $5 \mathrm{~mm}$ compr. Sementes elipsoides, 0,8-1 mm compr.

Material selecionado: Sem localidade, 1.VIII.1838, G. Gardner 1863 (NY). Aiuaba, Lagoa Rosilio, Estação Ecológica, 20.V.2003, L.Q. Matias 435 (EAC). Camocim, Lagoa de Tatajuba, 28.IV.1998, L.Q. Matias (EAC26925). General Sampaio, RPPN Fancy Nunes, Fazenda Natália, 1.IX.2008, M.F. Moro 477 (EAC). Jati, área onde será construido o Reservatório Porcos, 17.VIII.2011, J.V.A. Ferreira 122 (HUEFS). Lavras da Mangabeira, Açude Rosário, 10.X.2012, A.S. Dias (EAC54029). Missão Velha, Geopark Araripe, Geossítio Cachoeira da Missão Velha, 6.VI.2012, V.M. Cotarelli 1828 (HVASF).

Hydrothrix gardneri é endêmica da região semiárida do Brasil, ocorrendo principalmente nos estados da Região Nordeste, mas são encontradas populações no norte de Minas Gerais (Hooker 1887; BFG 2015; Sousa 2017). No Ceará, as populações podem ocorrer no noroeste, com frequência em riachos, rios e lagoas temporárias no semiárido (Fig. 1, quadrículas A2, C4, F3, G5, H5). Gardner coletou em 1838 o espécime tipo de H. gardneri ( $n^{\circ} 1863$ ) no estado do Ceará. A espécie é facilmente diferenciada por serem sempre plantas submersas com folhas lineares em uma filotaxia verticilada e pelas suas inflorescências com duas flores pequenas amarelas, envolvidas por uma bractéola, que se abrem simultaneamente, lembrando uma única flor (pseudanto).

\section{Pontederia L., Sp. P1. 1: 288. 1753.}

Ervas emergentes ou flutuantes fixas. Folhas alternas, dísticas, basais ou ao longo do caule, emersas, raramente flutuantes, pecioladas; pecíolos não inflados, cilíndricos; limbos elípticos a arredondados ou triangulares; ápice agudo a arredondado; base atenuada, truncada, arredondada ou cordada a sagitada. Eixo reprodutivo longo. Bráctea semelhante às folhas. Inflorescências tirsos espiciformes, formadas por unidades de cincinos, 8-multi-floras, 1-5 por unidade de cincínio; pedúnculo longo; bractéola oboval a lanceolada, frequentemente cimbiforme, fechada; raque glabra, pubescente ou vilosa. Flores lilases, azuis ou brancas, tubo do perigônio com face externa pubescente ou vilosa; lobos externos com margem inteira elíptico, lobos internos com margem inteira, oval $(3+3)$, lobo mediano posterior com guia de néctar; estames 6, filetes cilíndricos, brancos ou lilases a azulados, pubescentes, anteras homomorfas, oblongas a sagitadas, basifixas, castanhas ou azuladas; ovário esverdeado ou lilás, glabro, trilocular, apenas um lóculo fértil, uniovulado, estilete lilás a esbranquiçado, glabro ou pubescente, estigma capitado a trilobado, branco. Utrículo esverdeado ou castanho, antocarpo bem desenvolvido, verde, torcido no ápice, equinado ou alado. Sementes ovoides, lisas.

O gênero Pontederia é representado por plantas geralmente robustas, constituindo nas formas com maior comprimento dentre as Pontederiaceae. Suas inflorescências são complexas em tirsos compostos por conjuntos de cincinos sésseis, com flores geralmente pequenas e bem caracterizadas pelo ovário com apenas um lóculo fértil contendo um único óvulo. Tal ovário dá origem a um utrículo com o perigônio persistente, formando um antocarpo equinado ou alado, características únicas dentre as Pontederiaceae (Lowden 1973; Sousa \& Giulietti 2014). Pontederia é composto por cerca de seis espécies, apresentando distribuição nos 
continentes americanos e na Australásia (Crow 2003; Lowden 1973). As seis espécies do gênero são encontradas no Brasil (Lowden 1973; BFG 2015; Sousa 2017) e, para o Ceará, apenas a espécie Pontederia parviflora Alexander é registrada.

4.1. Pontederia parviflora Alexander, N. Amer. Fl. 19: 59. 1037. Figs. 3r-t; 5d

Erva emergente, ereta, 30-110 cm alt. Folha emersa, alterna, dística, basal; pecíolo nunca inflado, 27-85 × 0,5-1 cm, verde, glabro; limbo cordiforme a amplo oval, 7-21 × 3-7,5 cm, verde, acródromo, glabro; lígula fibrosa, 8-10 cm compr., vinácea, ápice obtuso. Eixo reprodutivo 30-90 cm compr. Bráctea semelhante às folhas. Tirso espiciforme ca. 100-flora; pedúnculo 4-25 cm compr.; bractéola oboval, 3,5-6 mm compr., ápice arredondado, levemente retuso, mucronado; raque 4,5-6 cm compr., pilosa. Flores com face externa do tubo do perigônio vilosa; lobos externos ca. $7 \mathrm{~mm}$ compr., 1 posterior e 2 anteriores elípticos, brancos, lobos internos 6-8 mm compr., 1 anterior oval, branco, com mácula amarela basal e 2 posteriores elípticos (3+3), brancos; estames 6, 3 maiores, filetes 1-9 mm compr. brancos, pubérulos; anteras oblongas, ca. 0,8 mm compr., castanho claras; ovário 1,5-1,6 mm compr., esverdeado, glabro; estilete 1-7 mm compr., branco, pubérulo na porção apical; estigma capitado a trilobado, branco. Utrículo ca. $1 \mathrm{~mm}$ compr., alado. Sementes não vistas.

Material selecionado: Caucaia, Catuana, Lagoa Pedro Lopes, 26.IX.2001, A.S.F. Castro 1082 (EAC). Crateús, Xavier, baixada da serra das almas, 24.VI.2003, L.Q. Matias 450 (EAC). Crato, 28.VI.1937, P. Luetzelburg 28624 (IPA). Iguatu, CE-060, 13.V.2010, L.R.O. Normando 038 (EAC). Independência, BR-226, 12.V.2011, L.Q. Matias 617 (EAC). São Gonçalo do Amarante, Pecém, Lagoa do Gereraú, 10.XI.2007, M.F. Moro 283 (EAC). Sobral, açude na margem da estrada, IV.2004, L.P. Félix 10413 (EAC).

Pontederia parviflora ocorre na América Central e América do Sul, do Panamá até a Região Centro-Oeste do Brasil (Lowden 1973). Para o Brasil, por muito tempo as suas populações foram referidas como restritas ao Pantanal brasileiro (BFG 2015). Atualmente os registros indicam ocorrência nas regiões Sudeste (Minas Gerais, São Paulo), Centro-Oeste (Distrito Federal, Goiás, Mato Grosso do Sul, Mato Grosso), Norte (Tocantins) e Nordeste (Ceará, Maranhão, Paraíba, Piauí) (Sousa 2017). No Ceará, suas populações podem ser observadas desde as lagoas costeiras do noroeste do estado até as lagoas temporárias do semiárido (Fig. 1, quadrículas B3, B5, B6, D1, E3, F5). A espécie apresenta grande semelhança com Pontederia cordata L. (sem registro para o Ceará), pois vegetativamente apresentam formas de crescimento e folhas semelhantes, sendo a base dos pecíolos de $P$. parviflora frequentemente vináceas. As flores também apresentam grande semelhança, sendo em P. parviflora sempre brancas e com tricomas bem compridos e sem uma célula globosa na base ( $v s$. flores geralmente azuladas, com tricomas curtos e uma célula globosa na base em $P$. cordata).

\section{Referências}

Alexander EJ (1939) Pontederiaceae. Lloydia 2: 170.

BFG - The Brazil Flora Group (2015) Growing knowledge: an overview of seed plant diversity in Brazil. Rodriguésia 66: 1085-1113.

Castellanos A (1958) Las Pontederiaceae del Brasil. Arquivos do Jardim Botânico do Rio de Janeiro 16: 147-236.

Ceska A (1986) More on techniques for collecting aquatic and marsh plants. Annals of the Missouri Botanical Garden 73: 825-827.

Cook CDK (1996) Aquatic Plant Book. SPB Academic Publishing, Amsterdam. 228p.

Cook CDK (1998) Pontederiaceae. In: Kubitzki K (ed.). The families and genera of vascular plants. Vol. 4 . Springer, Berlin. Pp. 395-403.

Crow GE (2003) Pontederiaceae. In: Hammel BE, Grayum MH, Herrera C \& Zamora N (eds.). Manual de plantas de Costa Rica. Vol. III: Monocotiledóneas. Missouri Botanical Garden Press, St. Louis and Instituto Nacional de Biodiversidad, Santo Domingo de Heredia, Costa Rica. Pp. 822-828.

Eckenwalder JE \& Barrett SCH (1986) Phylogenetic systematics of Pontederiaceae. Systematic Botany 11: 373-391.

França F \& Melo E (2006) Aquatic vascular plants in the Semi-arid of Bahia. In: Queiroz LP, Rapini A \& Giulietti AM (eds.). Towards greater knowledge of the brazilian semi-arid biodiversity. Ministério de Ciências e Tecnologia, Brasília. Pp. 69-72.

Giulietti AM, Conceição AA \& Queiroz LP (2006) Diversidade e caracterização das fanerógamas do Semi-árido Brasileiro. Instituto do Milênio do Semiárido. Vol. 1. Ministério da Ciência e Tecnologia, Brasília. Pp. 15-364.

Graham SW \& Barret SCH (1995) Phylogenetic Systematics of Pontederiales. In: PJ Rudall, PJ Cribb, DF Cutler \& CJ Humphries (eds.). Monocotyledons: systematics and evolution. Royal Botanic Gardens, Kew. Pp. 415-441.

Graham SW, Kohn JR, Morton BR \& Eckenwalder JE (1998) Phylogenetic congruence and discordance among one morphological and three molecular data sets from Pontederiaceae. Systematic Biology 47: 545-567. 
Graham SW, Olmstead RG \& Barrett SCH (2002) Rooting phylogenetic trees with distant outgroups: a case study from the Commelinoid Monocots. Molecular Biology and Evolution 19: 1769-1781.

Haynes RR (1984) Techniques for collecting aquatic and marsh plants. Annals of the Missouri Botanical Garden 71: 229-231.

Henry-Silva GG, Moura RST \& Dantas LLO (2010) Richness and distribution of aquatic macrophytes in Brazilian semi-arid aquatic ecosystems. Acta Limnologica Brasiliensia 22: 147-156.

Hooker JD (1887) On Hydrothrix, a new genus of Pontederiaceae. Annals of Botany 1: 89-94.

Horn CN (1985) A systematic revision of the genus Heteranthera (sensu lato; Pontederiaceae). Ph.D. dissertation. University of Alabama, Alabama. 206p.

IPNI (2015) The international plant names index. Disponível em $<$ http://www.ipni.org $>$. Acesso em 7 abril 2016.

Kuo-fang W \& Horn CN (2000) Pontederiaceae. In: Flora of China. Disponível em $<\mathrm{http}$ ://www.efloras. org/florataxon.aspx?flora_id=2\&taxon_id=10722>. Acesso em 14 janeiro $20 \overline{1} 4$.

Lowden RM (1973) Revision of the genus Pontederia L. Rhodora 75: 426-483.

Machado O (1947) Uma nova espécie de Hydrothrix Hook. f. Revista Brasileira de Biologia 7: 123-125.

Matias LQ \& Sousa DJL (2011) Alismataceae no estado do Ceará, Brasil. Rodriguésia 62: 887-900.

Matias LQ, Amado ER \& Nunes E (2003) Macrófitas aquáticas da lagoa de Jijoca de Jericoacoara, Ceará, Brasil. Acta Botanica Brasilica 17: 623-631.

Ness RW, Graham SW \& Barrett SCH (2011) Reconciling gene and genome duplication events: using multiple nuclear gene families to infer the phylogeny of the aquatic plant family Pontederiaceae. Molecular Biology and Evolution 28: 3009-3018.

Neves EL, Leite KRB, França F \& Melo E (2006) Plantas aquáticas vasculares em uma lagoa de planície costeira no município de Candeias, Bahia, Brasil. Sitientibus 6: 24-29.

Novelo A \& Ramos L (1998) Pontederiaceae. In: Rzedowski GC \& Rzedowski J (eds.). Flora del bajío de regiones adyacentes. Vol. 63. Instituto de Ecología AC \& la Comisión Nacional para el Conocimiento y Uso de la Biodiversidad, Michoacán \& México. Pp. 1-19.

Radford AE, Dickison WC, Massey JR \& Bell CR (1974) Vascular plant systematics. Harper \& Row, New York. 891p.

Schultz AG (1942) Las Pontederiáceas de la Argentina. Darwiniana 6: 4-39.

Schwartz O (1926) Anatomische, morphologische und systematische Untersuchungen über die Pontederiaceen. Beihefte zum Botanischen Centralblatt 42: 263-320.

Sculthorpe CD (1967) The Biology of Aquatic Vascular Plants. Edward Arnold, London. 610p.

Seubert M (1847) Pontederiaceae. In: Martius CFP, Eichler AW, Urban I (eds.). Flora Brasiliensis. Frid. Fleischer, Lipsiae. Vol. 3, pars 1, pp. 85-96.

Sousa DJL (2017) Pontederiaceae in Flora do Brasil 2020 (em construção). Jardim Botânico do Rio de Janeiro. Disponível em <http://floradobrasil.jbrj.gov.br/ reflora/floradobrasil/FB197>. Acesso em julho 2017.

Sousa DJL \& Giulietti AM (2014) Flora da Bahia: Pontederiaceae. Sitientibus Série Ciências Biológicas 14: 14-30.

Sousa DJL, Scatena VL, Giulietti AN \& Oriani A (2016a) Morphological and anatomical patterns in Pontederiaceae (Commelinales) and their evolutionary implications. Aquatic Botany 129: 19-30.

Sousa DJL, Barrett SCH, Leme da Cunha N \& GiuliettiHarley AM (2016b) Genus Eichhornia Kunth (Pontederiaceae) 780. Rapid color guides. Field Museum, Chicago Ilhinois. Disponível em $<$ http:// fieldguides.fieldmuseum.org/guides/guide/780>. Acesso em julho 2017.

The Plant List (2013) Version 1.1. Published on the Internet. Disponível em <http://www.theplantlist. org $>$. Acesso em janeiro 2016.

Thiers B [continuamente atualizado] Index Herbariorum: a global directory of public herbaria and associated staff. New York Botanical Garden's Virtual Herbarium. Disponível em $<$ http://sweetgum.nybg. org/science/ih/> . Acesso em 10 novembro 2010. 


\section{Lista de exsicatas}

Araújo JRS HDELTA1214 (1.1). Araújo FS 345 (2.1). Albuquerque AC 04 (1.1). Bezerra P EAC787 (1.4), 207 (1.4). Boto MMP HDELTA1235 (1.1). Castro AJ EAC7104 (1.4), HUESB 6350 (1.4). Castro ASF 1768 (1.2), 2161 (1.2), 2111 (1.3), 1187 (2.1), 2504 (2.1), 372 (2.2), 1082 (4.1). Cavalcanti FS 447 (1.4), EAC29991 (2.3). Costa DMF 04 (1.1). Cotarelli VM 1828 (3.1), 2215 (1.1), 2552 (2.1). Curran HW 2176 (1.4). Cutler HC 8373 (1.2), 8378 (1.4). Dahlgren BE 841 (1.4). Dias AS EAC54029 (3.1). Drouet FE 2332 (1.2), 2608 (1.3), 2219 (1.4), 2514 (1.2), 2612 (1.2), 2649 (1.3), 2179 (1.3), 2176 (1.4), 2414 (2.1), 2649 (1.3). Farias DLS 24 (1.1). Félix LP 10413 (4.1). Fernandes A EAC21215 (1.2), EAC21232 (1.2), EAC2113 (1.4), EAC2114 (1.4). Ferreira JVA 122 (3.1). Figueiredo MA MAC48631. Gardner G 1863 (3.1), 1864 (2.3). Gomes V 339 (1.4), 1199 (1.4). Horn CN 541 (1.1), 538 (1.2), 539 (1.4), 537 (2.1), 540 (2.1). Landim B 26 (1.4). Lima BG 288 (4.1). Lima-Verde LW EAC21492 (1.4), 284 (2.1). Loiola MIB 2084 (1.2), 194 (3.1). Luetzelburg P 28095 (1.1), 26839 (1.1), 28621 (1.1), 28624 (4.1). Marreira EM 226 (1.4). Martins Filho RT EAC49095 (1.1). Matias LQ 589 (1.1), 585 (1.1), 459 (1.2), 457 (1.2), 486 (1.2), 686 (1.2), 627 (1.2), $456(1.3), 482$ (1.3), 619 (1.3), 694 (1.3), 24 (1.4), 70, (1.4), 68 (1.4), 419 (1.4), 713 (1.5), 451 (2.1), $470(2.1), 452(2.1), 431(2.1), 380(2.1), 618(2.1), 620(2.1), 717$ (2.1), 714 (2.2), 713 (1.5), 471 (2.3), EAC26925 (3.1), 435 (3.1) s.n EAC32547 (4.1), 450 (4.1), 617 (4.1), EAC80793 (1.4). Melo ACB HDELTA1213 (4;1). Miranda AM 6269 (2.1). Morais ACA EAC47199 (1.4). Moro MF 477 (3.1), 283 (4.1). Normando LRO 190 (1.2), 03 (1.2), 116 (1.2), 521 (1.2), 300 (1.3), 238 (1.3), 454 (1.3), 426 (1.3), 458 (1.3), 38 (4.1). Nunes E EAC6212 (1.4). Paiva JRA 04 (1.1), 12 (1.1). Paulo C 08 (1.1). Silva FFS 120 (2.1). Silva MFS 627 (1.2). Sousa DJL 99 (1.2), 98 (1.4), 01 (2.1), 19 (2.1). Souza VC 28695 (2.1). Tabosa AB EAC45502 (1.1), 42 (1.2), 02 (1.4), 01 (1.4), 05 (2.1), EAC45071 (2.1). Trigueiro E EAC31620 (1.4).

Editor de área: Dr. Luiz Menini Neto Artigo recebido em 18/01/2017. Aceito para publicação em 28/09/2017. $($ (c) BY This is an open-access article distributed under the terms of the Creative Commons Attribution License. 